\title{
Sensory Evaluation of Jam Produced From Jackfruit (Artocarpus heterophyllus)
}

\author{
Ihediohanma.N.C. ${ }^{1}$,Okafor D.C. ${ }^{1}$ and Adeboye, A.S. ${ }^{2}$ \\ ${ }^{I}$ Department of Food Science \&Technology, Federal University of Technology, Imo, Owerri, Nigeria \\ ${ }^{2}$ Department of Food Technology, Moshood Abiola Polytechnic, Abeokuta.
}

\begin{abstract}
The work evaluated the sensory quality of jam produced from Jackfruits (Artocarpus heterophyllus). Pulp was extracted from jackfruits obtained from new market Owerri, Imo State. The pulp produced was mixed with prepared and standardized citric acid-sugar syrup, allowed to cook on constant boiling/stirring and the gelatinization temperature and the time were taken and recorded. The prepared jam was carefully poured in steam/ethanol sterilized jam bottles and cocked immediately the jam was allowed to cool. The cooled jam was served to panelist to compare sensory acceptability of the jackfuit jam alongside pineapple and orange jam. Sensory evaluation revealed significant difference $(P>0.05)$ in colour and aroma of the samples while there was no significant difference $(P<0.05)$ in the texture and sweetness of samples tested. The study concludes that jackfruit (Artocarpus heterophyllus). is a promising source of pectin which can be successfully applied in food gel system such as fruit jams.
\end{abstract}

\section{Introduction}

Jam is an example of fruit preserve usually made from pulp and juice of one fruit (whole fruit). It can be defined as cooked and gelled fruit purses packaged for long term storage which is normally used as bread spread, fillings and food jellies. The preparation of fruit jam traditionally involves the use of pectin as a gelling agent, although sugar or honey and citric acid may be added as well (Pattern, 2001). Good jam has a soft even consistency without distinct pieces of fruit, a bright colour, good flavour and a semi-jelled texture that is easy to spread but has no free liquid (Isabel and William, 1990).

Pectin refers to a group of diverse complex polysaccharides found in the primary cell wall and intercellular space (middle lamella) of plants cells. It is most abundant in young tissues and are the characteristic constituents of fruits (Ihekoronye and Ngoddy, 1985). Pectin is a high molecular polymeric carbohydrate which is present in all plants. It is a purified carbohydrate product generally obtained from the acid extraction of the inner portion of the citrus fruit peels and apple pomace (Meloanand Pomeranze, 1980). Pectin is mainly used in food as a gelling of boiled fruits preparations. Today, it is used in fillings, sweets, and as a source of dietary fibre in food. Pectin is also used as a thickening agent, water binders and can be used to stabilize acidic protein drinks, such as drinking yoghurt and as a fat replacer (Coulate, 1989). Though a natural part of human diet pectin does not contribute significantly to nutrition (Belitz et al, 2004). Morton, (1987) has the opinion that in human digestion, pectin passes through the small intestine and colon, micro-organisms degrade pectin and liberate short-chained fatty acids that have positive influence on health (prebiotic effect). Dietary incorporation of pectin appears to affect several metabolic and digestive processes; those of primary interest are the effect on lowering glucose absorption and cholesterol levels (Peter, 2008). These were supported by other studies in both animal models and human subject that pectin $(20-30 \mathrm{~g} / \mathrm{day})$ added to a test meal significantly reduced the rate of glucose uptake, with concomitant reduction of serum insulin production.

With the exception of other fruits in making jam, little research has been done on the utilization of other tropical fruit such as jack fruit ( Artocarpus heterophyllus), which is found as a potential fruit and can be utilized in making jam in order to reduce harvest losses and increase the utilization concept. The fruit is suspected to taste like fruit gum, bananas and nectarines combined.

It is a very sweet and refreshing fruit that has thick and hard rinds which are often spoiled or stripped with a fleshly juicy crispy centre. It can be round, oblong or spherical in shape, colour, sugar content and flavour are the chief attributes of a ripe jack fruit. It might not need any other fruit in addition because it has high pectin and high sugar contents. Fruits for jam preparation such as orange, lemon, grape and pineapple have sufficient pectin and acid to yield good jelly.

The aim and objective of this work is therefore to produce jam using jack fruit and using statistical sensory evaluation to determine its acceptability or otherwise. 


\section{Production of Jackfruit Jam}

\section{Materials and methods}

The jackfruits used for the work were purchased from New Market Owerri, Imo State Nigeria. The Jackfruit were washed thoroughly with clean water and cut into small sizes. The seeds were carefully removed using knife, and the jackfruit peeled then blended using Kenwood blender Model 5024ID. The juices from the fruits were sieved with muslin cloth and the fruit pulp kept in clean bowl. $300 \mathrm{ml}$ of water to $250 \mathrm{~g}$ of sugar was used to prepare sugar syrup. The syrup was boiled at $100^{\circ} \mathrm{C}$ and $4 \mathrm{~g}$ of citric acid was added, and allowed to boil again until a slippery feel to gel was formed, it was placed acid to cool.200g of the fruit pulp was concentrated and the prepared syrup added on boiling, it was allowed to cook on constant boiling/stirring and the gelatinization temperature and the time were taken and recorded.At the end, the prepared jam was carefully poured in steam/ethanol sterilized jam bottles and cooked immediately the jam was allowed to $\operatorname{cool}(\mathrm{AOAC}$, 2006).

\section{Determination of Total Dissolved Solids (TDS)}

The total dissolved solids of the samples were determined using a total dissolved solids meter (ATP Instrumentation -TDS- 5031- Meter High range. ATP Instrumentation, UK.). The instrument probe was inserted into a beaker containing the sample and allowed for a few minutes until the reading equilibrated.

\section{Sensory Evaluation}

Sensory evaluation of the jam samples were conducted as described by Iwe (2002) using 10-members panel randomly selected from the university community. The samples were packaged in a transparent jam bottles and presented in a coded manner. The sensory quality attributes of the samples were colour, taste, aroma and sweetness.

In the questionnaire presented to the panelists, they were requested to observe and taste each sample as coded with bread provided and grade them based on a 4-point hedonic scale showing least acceptable to most acceptable in all attributes.

They were also provided with potable water to rinse their mouth after evaluating each sample to check taste interference.

\section{Results and discussion}

Table 1 showed the mean sensory score of Jack fruit, Pineapple and Orange jam, The scoreswere analyzed in terms of colour, aroma, texture and sweetness The result gotten from the analysis revealed that sample B (pineapple) has the best acceptable colour with the mean value of $8.1 \pm 0.99$, while sample A (jam from jackfruit) has the lowest colour $5.1 \pm 2.03$. However, there was no significant difference between $\mathrm{B}$ and $\mathrm{C}$ least acceptable (orange and pineapple jam respectively).

For aroma sample $\mathrm{B}$, the highest value of $8.4 \pm 1.71$ while sample A has the lowest value of $4.7 \pm 1.95$. The result showed that there were no significant different between sample B and $\mathrm{C}$ pineapple and orange but there is significant different in sample A (Jack fruit jam)

In texture, sample $\mathrm{C}$ has the highest value of $7.2 \pm 1.03$, but no significant difference in sample $\mathrm{A}$ and B

In sweetness sample $C$ has the highest value of $8.4 \pm 1.17$ while sample $A$ has the lowest value of $7.1 \pm 2.13$, but there is no significant different in sample A, B, and C in terms of sweetness.

The result of sensory evaluation shows that sample B (Pineapple) is most acceptable followed by $\mathrm{C}(\mathrm{Orange})$.. while sample A has the least colour and aroma.

Table 1:Mean Sensory Score of Jackfruit, Pineapple and Orange jam

\begin{tabular}{lllll} 
Samples & Colour & Aroma & Texture & Sweetness \\
\hline Jackfruit Jam (A) & $5.1 \pm 2.03^{\mathrm{b}}$ & $4.7 \pm 1.95^{\mathrm{b}}$ & $6.1 \pm 1.37^{\mathrm{a}}$ & $7.1 \pm 2.13^{\mathrm{a}}$ \\
Pineapple Jam (B) & $8.1 \pm 0.99^{\mathrm{a}}$ & $8.4 \pm 1.71^{\mathrm{a}}$ & $6.1+1.79^{\mathrm{a}}$ & $7.9 \pm 1.79^{\mathrm{a}}$ \\
Orange Jam (C) & $7.6+1.08^{\mathrm{b}}$ & $8.0 \pm 0.82^{\mathrm{a}}$ & $7.2 \pm 1.03^{\mathrm{a}}$ & $8.4 \pm 1.1 .7^{\mathrm{a}}$ \\
\hline LSD & $\mathbf{1 . 3 2 4}$ & $\mathbf{1 . 4 4 0}$ & $\mathbf{1 . 3 1 4}$ & $\mathbf{1 . 6 0 1}$
\end{tabular}

Values are means \pm S.D for 10 determinations

Means \pm S.D with same alphabetical superscript along the same column are not significantly different.

\section{Conclusion And Recommendation}

The results obtained from the study showed that jackfruit (Artocarpus heterophyllus) is a promising source of pectin which can be successfully applied in food gel system such as fruit jamsjellies and fillers etc. However, this tropical fruits wastes a lot due to underutilization. If optimally utilized for pectin and jam production could significantly reduce the present wastage and waste disposal problems encountered while handling jack fruits, thereby reducing post-harvest losses. From the results obtained, it showed that jack fruit can 
be industrial source pectin. This lower $\mathrm{pH}$ tends to create more preserved and stable jam which is less prone to microbial spoilage. It is therefore recommend that detailed and improved research should be done on the pectin from these lesser known sources to produce better jam with improved sensory attributes. It is therefore recommended that production of pectin using jack fruit be encouraged and use of jam produced from jack fruit could be an innovation.

\section{References}

[1]. OAC 2006. Official Method 963.19 "Official Methods of Analysis"., 18th Edition. Horwitz W, George LW (eds.). Association of Official Analytical Chemists, Maryland.

[2]. Blitz, H.D. and Grosch, W. ( 2004) Sources of Natural Phenolic Antioxidant. Food Chemistry Springer Berlin. Pp69-73

[3]. Coulate, T.P. (1989). The Chemistry Food and its components, $2^{\text {nd }}$ ed. Cambridge.

[4]. Iheoronye, A.I. and Ngoddy, P.O.(1985) "Integrated Food Science and Technology for the Tropics" Macmillan publishers. London $\mathrm{Pp}$

[5]. Isabel, D.W. and Willisam, S. (1990). "Making Jams, Marmalades, Preserves and Conserves" University of Minnesota Extension School. http//www.enten.umn.edu/distribu/nutria/DJ1088.html.

[6]. Iwe, M. O. (2002). Handbook of Sensory Methods and Analysis. Rejoint Communication Services Ltd Uwani Enugu. Pp $40-83$

[7]. Meloan, C. and Pomeranz, Y. (1980). Pectin In: Food analysis Laboratory Experiment, $2^{\text {nd }}$ ed. AVI Pub. Co. Inc Westport, Connecticut U.S.A. Pp. 136-137.

[8]. Morton J. (1987). Jackfruit In: Food of Warm Climates. Pp. 58-64. Retrieved October 12, 2010, from http://www.hort.purdue.edu.newcrop/morton/jackfruittars.htm up date 10/12/2010.

[9]. Patten, M. (2001). Basics In: Jams, Preserves and Chutneys. Handbook (2004 reprint ed.) Grub street books. (ISBN 1902304721.

[10]. Peter, J.H (2008) Dietary Agents that Target Gastrointestinal and Hepatic Handling of Bile Acids and Cholesterol. Journal of Clinical Lipidology,2(2)Pp4-10 